\title{
Study of Nutritional, Phytochemicals and Functional Properties of Mango Kernel
}

\section{Powder}

\section{PRAVIN OJHA ${ }^{1 *}$, SHREEJANA RAUT ${ }^{2}$, UJJWOL SUBEDI ${ }^{1,}$ AND NAWARAJ UPADHAYA ${ }^{2}$}

${ }^{1}$ Food Research Division, Nepal Agricultural Research Council, Khumaltar, Lalitpur. Nepal

${ }^{2}$ Padmashree International College, Tinkune, Kathmandu, Nepal

\begin{abstract}
Food ingredient with good nutritional and phytochemical properties is always in search. This research was conducted to study the effect of different treatments, namely soaking and blanching, on nutrient, phytochemical, and functional properties of mango kernel powder (MKP). Three treatments were carried out to produce MKP, which were soaking (48 h), heat treatment/blanching $\left(45^{\circ} \mathrm{Cfor} 2 \mathrm{~min}\right)$, and control. The seed was cut into four pieces and dried in cabinet drier for $7 \mathrm{~h}$ at $60{ }^{\circ} \mathrm{C}$ until it becomes brittle. The kernel was ground to pass through a $0.85 \mathrm{~mm}$ size sieve. Powder from three treatments was subjected to nutrient analysis, phytochemical analysis, and functional properties evaluation. Crude fat increased significantly $(p<0.05)$ in soaked mango kernel powder, while the treatment decreased total ash, iron, calcium, and phosphorous significantly ( $p<0.05)$. Oil absorption capacity $(O A C)$, water absorption capacity (WAC), and wettability of MKP decreased significantly ( $<<0.05)$ after treatment, while bulk density increased significantly $(p<0.05)$. The wettability of soaked MKP decreased significantly $(p<0.05)$, while it significantly increased for heated MKP $(p<0.05)$. The heat treatment produced a significant reduction $(p<0.05)$ in ascorbic acid (18.24\%), polyphenol content (4.7\%), tannin (76.44\%), and flavonoid (7.38\%) compared to untreated flour while soaking result in a significant reduction $(p<0.05)$ in ascorbic acid $(13.1 \%)$, polyphenol $(3.47 \%)$, tannin $(63.73 \%)$, and flavonoid $(21.76 \%)$. The antioxidant activity was found to be significantly less $(68.33 \%)$ in heat-treated MKP compared ( $<<0.05)$ to the soaked MKP (79\%) and untreated MKP (84.33\%). A positive correlation was found between the polyphenol and antioxidant activity. It can be concluded that MKP without treatment can be explored for composite flour as phytochemicals and functional property were found to be better than treated flour.
\end{abstract}

Keywords: Angle of Repose, Antioxidant Activity, Mango Kernel, Polyphenol, Tannin

\section{Introduction}

Mango (Mangifera indica) is the king of the fruit and is popular worldwide due to its exotic flavor and delicious taste. Around $20 \%$ of mango are processed for products such as puree, nectar, leather, canned slice and chutney, juices, fruit bars, and pies. During the processing of ripe mango, its peel, and seed are generated as a waste, which is approximately $40-50 \%$ of the total fruit weight (Ashoush and Gadallah, 2011). The mango seed represents about 20 $\%$ of the total weight of fruit, while the kernel is $45-85 \%$ of the seed (Arogba, 1997; Solis-Fuentes and Duran-deBazua, 2011). Mango seed accounts for around 9.42 million tons from 47.1 million tons mango (Altendorf, 2017).

As reviewed by Schieber et al. (2001), mango seed kernel is rich in minerals like potassium, calcium, copper, and zinc along with phytosterols. Mango kernel powder (MKP) is a rich source of ascorbic acid, carotenoid, polyphenol, and also exhibits good anti-oxidant property. Antioxidant compound from mango kernel was extracted and added in buffalo ghee to study the stability of ghee (Puravanekara et al., 2000). Mango seed kernel also possesses anti-microbial activity, which shows its potentiality as a natural antibiotic and antifungal (Mutua et al., 2017). The minced beef with $3 \%$ MKP shows the lowest microbial count after storage periods of $48 \mathrm{~h}$ in refrigerated condition (Gadallah and Fattah, 2011).
Despite high nutritional and health benefits, mango kernel is a major byproduct of the mango processing industry and commercial exploration is negligible (Torres-Leon et al., 2016 and Jahurul et al., 2015). Research has been carried out to partially substitute wheat flour by MKP for the formulation of cookies, biscuits, and bread (Ashoush and Gadallah, 2011; Bandyopadhyay et al., 2014; Menon et al., 2014). This agro-waste has high tannin content as reported by Arogba (1999), which may affect the organoleptic quality (astringent taste) of bakery products or other composite flour products (Eleazu et al., 2014). Many researchers have reviewed the nutritional, phytochemicals, and functional properties of MKP. Abdalla et al. (2007) found that mango seed kernel of Egyptian varieties is rich in all eight essential amino acids. Sogi et al. (2013) found that drying methods affect the polyphenol, anti-oxidant activity, and functional properties of MKP. Torres-Leon et al. (2016) reviewed that mango kernel oil does not contain trans-fatty acid, and carry the great potentiality for the food industry.

Many kinds of research are focused to recognize the cheap source of flours to substitute wheat flour, either partially or completely (Noorfarahzilah et al., 2014). For the utilization of flour in composite flour, the functional property of powder should be assessed to explore the potentiality. Functional properties are related to the interrelationship between composition (mainly protein and carbohydrate), structure, molecular confirmation, and physiochemical 
properties of food (Chandra et al., 2015). Many authors have researched the formulation of bread and biscuit by incorporating mango kernel powder (Arogba, 1999; Legesse and Emaise, 2012; Menon et al., 2014). However, research is lacking on the processing effect on the functional properties and phytochemical constituents of mango kernel powder.

The concept of healthy ingredient has raised the interest in the use of flour with an ample amount of phytochemicals (Wang and Bohn, 2012). So, this research attempt to highlight the effect of different treatments on nutritional quality, functional properties, and phytochemicals components of mango kernel powder and there might be a possibility of commercializing mango kernel powder.

\section{Materials and methods \\ Materials}

Ripe mango fruits of Alfonso (Magniferra indica) variety were bought from the local vegetable market (Kuleshwor) of Kathmandu. The chemicals used for the analysis were of analytical grade, which was. 2,2-diphenyl-1-picrylhydrazyl (DPPH), Phenol reagent, gallic acid, and methanol, purchased from Sigma-Aldrich Company (Germany), Finar Limited(India), LOBA Chemie(India) and Fisher Scientific (India) respectively. Sodium tungstate and phosphomolybdic acid for Folin-Denis reagent were purchased from Fisher Scientific, India. Sodium tungstate and phosphomolybdic acid for Folin-Denis reagent, Sodium hydroxide, concentrated Sulphuric acid, tannic acid, and potassium permanganate were purchased from Fisher Scientific, India.

\section{Preparation of mango kernel powder}

Mango seed was manually removed and soaked in water for $30 \mathrm{~min}$. The kernel from mango seed was manually removed by using a stainless knife. The mango kernel was subjected to three treatments, blanched in warm water (2 min for $45^{\circ} \mathrm{C}$, water: seed=2:1), soaking ( $48 \mathrm{~h}$, water: seed $=2: 1$ ) (Yatnatti, et al., 2014) and other was control. All the seeds were dried in cabinet drier at $60{ }^{\circ} \mathrm{C}$ for $7 \mathrm{~h}$. The dried seed was ground to pass through a $0.85 \mathrm{~mm}$ mesh size (HT/standard sieves).

\section{Proximate and mineral analysis}

The moisture content was determined by the hot-air oven method by drying the sample in a hot air oven at $105^{\circ} \mathrm{C}$ to constant weight as described by AOAC method number 930.15 (AOAC, 2005).

The protein content of mango kernel powder (MKP) were calculated from the nitrogen content measured by the Kjeldahl method as described by AOAC method number 920.152 (AOAC, 2005).

The fat content of the MKP was determined by solvent extraction by continuous extraction in a Soxhlet apparatus for 3 hours using petroleum ether as a solvent as mentioned in AOAC method number 991.36 (AOAC, 2005).

The crude fiber of MKP was determined as described by AOAC method number 934.01 and a total ash content of the MKP was determined as per AOAC method number
945.46 (AOAC, 2005).

Total carbohydrate content (Ranganna, 2002) was calculated by the difference method as in equation (i):

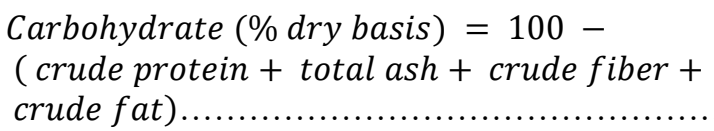

The calcium, iron, and phosphorous content of MKP were also determined by as per the method described by Ranganna (2002).

\section{Extract preparation, phytochemical quantification and antioxidant activity determination}

The MKP extract was prepared according to the method described by Sigdel et al. (2018) with some modification. Briefly, 1 gram of powder was kept under continuous shaking for 20 minutes with absolute methanol $(30 \mathrm{ml})$ and then filtered. A similar process was repeated twice and the final volume was made up of $100 \mathrm{ml}$ with methanol.

For the estimation of polyphenol content, the method described by Mahdavi et al., 2011 was followed with some modifications, where the prepared extract was treated with Folin- Ciocalteau solution and absorbance was measured at $760 \mathrm{~nm}$ in UV-Vis spectrophotometer (GENESYS ${ }^{\mathrm{TM}} 10 \mathrm{~S}$ Vis Spectrophotometer, Thermo Scientific ${ }^{\mathrm{TM}}$, Germany). Phenols react with phosphomolybdic acid in FolinCiocalteau reagent in alkaline medium and produce the blue colored complex (molybdenum blue). Gallic acid (as a standard phenolic acid) solution was used to prepare a standard curve as a reference. The result was expressed in mg gallic acid equivalent (GAE)/100 g.

For the determination of flavonoid content, the method described by Walvekar and Kaimal (2014) was followed using the aluminum chloride assay and measuring the absorbance at $510 \mathrm{~nm}$ in UV-Vis spectrophotometer. The principle of the aluminum chloride colorimetric method is that aluminum chloride forms acid-stable complexes with the C-4 keto group and either the C-3 or C-5 hydroxyl group of flavones and flavonols. Gallic acid solution is used for the preparation of a standard curve as reference. The result was expressed in $\mathrm{mg}$ gallic acid equivalent (GAE)/100 g.

For tannin content determination, Folin-Denish reagent was used for color development and absorbance was measured at $755 \mathrm{~nm}$ in UV-Vis spectrophotometer. The tannic acid solution was used to prepare a standard curve (Elgailani and Ishak, 2014). The result was expressed in mg tannic acid equivalent (TAE)/100 g.

The ascorbic acid content of mango kernel flour was determined by 2,6-dichloro-indophenol visual titration method as described by Ranganna (2002).

The antioxidant activity of ground powder was determined by the DPPH radical scavenging method as described by Walvekar and Kaimal (2014) with some modifications. The principle of DPPH method is based on the reduction of DPPH in the presence of a hydrogen 
donating antioxidant due to the formation of diphenyl picryl hydrozine. Briefly, $3 \mathrm{~mL}$ extract was mixed with 3 $\mathrm{mL}$ of $0.004 \%$ DPPH (2,2-diphenyl-1-picrylhydrazyl) solution and incubated in dark for $30 \mathrm{~min}$. The absorbance was taken at $517 \mathrm{~nm}$ using a UV-Vis spectrophotometer. Absolute methanol was used as a blank. The scavenging activity of the extract against the stable DPPH was calculated using the following equation (ii):

$$
\text { Scavenging activity }(\%)=(A-B) / A \times 100
$$

where A is the absorbance of DPPH and B is the absorbance of DPPH and the extract combination.

The calculated value was given by 10000 ppm ( 1 g powder in $100 \mathrm{ml}$ methanol) of mango seed extract.

\section{Functional properties}

The bulk density was determined according to the method described by Kanpairo et al. (2012). About $5 \mathrm{~g}$ of flour was put into a $25 \mathrm{~mL}$ graduated cylinder and tapped to a constant volume. The bulk density $\left(\mathrm{g} / \mathrm{cm}^{3}\right)$ was calculated using the formula as in equation (iii):

\section{Bulk density = Weight of flour $(g) /$ \\ flour volume (cm3)}

The method described by Onuegbu et al. (2014), was adopted to determine the oil absorption capacity (OAC). Refined soybean oil (density $0.92 \mathrm{~g} / \mathrm{ml}$ ) and the MKP was mixed in the ratio of 10:1 (volume/weight) and centrifuged at $2000 \mathrm{rpm}$ for 20 minutes. The difference in weight divided by the weight of the sample was measured as oil absorbed and calculated in percentage.

The method of Nwosu et al. (2014) was adopted for the determination of water absorption capacity (WAC). A similar process was carried out as OAC, where water was used instead of oil.

The gelation capacity of flour was determined as described by Chandra et al. (2015) with some modifications. The suspension (3-8\%) was prepared with $5 \mathrm{ml}$ distilled water in a test tube, heated for $1 \mathrm{~h}$, cooled rapidly in the refrigerator and kept for $2 \mathrm{~h}$ at $4^{\circ} \mathrm{C}$. The test tube was inverted to see if content will fall or slip off. The least gelation concentration is that concentration when the sample from the inverted test tube does not fall or slip.

Solubility was determined by using Nwosu (2011) method with slight modifications. The MKP $(0.5 \mathrm{~g})$ was mixed with $10 \mathrm{~mL}$ water and heated for $30 \mathrm{~min}$ in a water bath at $60^{\circ}$ C. The mixture was centrifuged at $3000 \mathrm{rpm}$ for $10 \mathrm{~min}$, the supernatant was recovered (weight measured). The supernatant was dried in the oven. The solubility percentage was calculated by using the formula as shown in equation (iv):

Solubility $=$ weight of supernatant after drying/ weight of $M K P * 100 \%$

Wettability was determined by the method described by Nwosu (2011) with some modifications. $1 \mathrm{~g}$ of the sample was poured from a test tube in a beaker containing $400 \mathrm{~mL}$ water and time was noted to completely wet the sample.

The method described by Shittu and Lawa (2007) was used to determine the angle of repose with slight modifications. Glass funnel was kept $2 \mathrm{~cm}$ from the base and powder was dropped from the funnel, the diameter of the base was measured. The angle of repose $(\varphi)$ was measured by the following relations as shown in equation $(\mathrm{v})$ :

Angle of Repose $\phi\left(^{\circ}\right)=\tan ^{-1} 2 h / D$

where, $\Phi=$ angle of repose $\left({ }^{\circ}\right)$; $\mathrm{h}=$ height of the pile $(\mathrm{mm})$; $\mathrm{D}=$ diameter of the pile $(\mathrm{mm})$.

\section{Research design and statistical analysis}

The research methodology used was a completely randomized design (CRD), with three treatments and triplicate analyses for each parameter. All the mean data obtained in this research work were compared by Analysis of Variance (ANOVA) with the help of SPSS (Statistical Package for the Social Sciences) (Version 16). Duncan's Post Hoc Test was used to determine significant differences $(p<0.05)$ between means. Results were expressed as the mean value \pm standard deviation of triplicate samples.

\section{Table 1}

Effect of blanching and soaking on the chemical composition of MKP.

\begin{tabular}{lccc}
\hline Sample & $\begin{array}{l}\text { Blanched } \\
\text { mango } \\
\text { kernel } \\
\text { powder }\end{array}$ & $\begin{array}{l}\text { Soaked } \\
\text { mango } \\
\text { kernel } \\
\text { powder }\end{array}$ & $\begin{array}{c}\text { Untreated } \\
\text { mango } \\
\text { kernel } \\
\text { powder }\end{array}$ \\
\hline Moisture (\%) & 2.87 & 3.60 & 2.97 \\
& $\pm 0.3^{\mathrm{a}}$ & $\pm 0.2^{\mathrm{b}}$ & $\pm 0.15^{\mathrm{a}}$ \\
\hline Crude protein (\%) & 6.50 & 6.47 & 6.13 \\
& $\pm 0.3^{\mathrm{a}}$ & $\pm 0.15^{\mathrm{a}}$ & $\pm 0.12^{\mathrm{a}}$ \\
\hline Crude fat (\%) & 9.63 & 10.17 & 9.53 \\
& $\pm 0.15^{\mathrm{a}}$ & $\pm 0.21^{\mathrm{b}}$ & $\pm 0.11^{\mathrm{a}}$ \\
\hline Total ash (\%) & 1.83 & 2.17 & 2.53 \\
& $\pm 0.06^{\mathrm{a}}$ & $\pm 0.11^{\mathrm{b}}$ & $\pm 0.11^{\mathrm{c}}$ \\
\hline Crude fiber (\%) & 3.47 & 3.53 & 3.77 \\
& $\pm 0.12^{\mathrm{a}}$ & $\pm 0.15^{\mathrm{a}}$ & $\pm 0.25^{\mathrm{a}}$ \\
\hline Available & 78.57 & 77.67 & 78.03 \\
carbohydrate (\%) & $\pm 0.29^{\mathrm{a}}$ & $\pm 0.15^{\mathrm{b}}$ & $\pm 0.15^{\mathrm{c}}$ \\
\hline Iron (mg/100 g) & 5.44 & 1.60 & 6.27 \\
& $\pm 0.15^{\mathrm{a}}$ & $\pm 0.20^{\mathrm{b}}$ & $\pm 0.11^{\mathrm{c}}$ \\
\hline Calcium (mg/100 g) & 115.00 & 96.67 & 199.33 \\
& $\pm 5.00^{\mathrm{a}}$ & $\pm 6.11^{\mathrm{b}}$ & $\pm 9.01^{\mathrm{c}}$ \\
\hline Phosphorous & 68.33 & 70.00 & 85.00 \\
(mg/100 g) & $\pm 1.52^{\mathrm{a}}$ & $\pm 2.00^{\mathrm{b}}$ & $\pm 5.00^{\mathrm{c}}$ \\
\hline All & & & \\
\hline
\end{tabular}

All data are the mean \pm standard deviation of its triplicates. Different letters in the same row indicate significant differences $(p<0.05)$. All parameters are on a dry basis except moisture.

\section{Results and Discussion}

\section{Chemical analysis of mango kernel powder}

The chemical analysis of mango kernel flour is shown in table 1 . The values were significantly different at $\mathrm{p}<0.05$. The crude protein $(\%)$, crude fat $(\%)$, total ash $(\%)$, and 
available carbohydrate (\%) range from 6.13-6.5, 9.53$10.17,1.83-2.53$, and 77.67-78.57 respectively.

Crude fat was increased significantly $(\mathrm{p}<0.05)$ in soaked mango kernel powder, while the treatment decreased total ash, iron, calcium, and phosphorous significantly $(\mathrm{p}<0.05)$. Okpala \& Gibson (2013) reported carbohydrate, crude fat, crude protein, total ash contents of mango kernel powder as $74.41 \%, 11.0 \%, 6.0 \%, 2.02 \%$ respectively. Abdalla et al. (2007) reported fat content $12.3 \%$ in the mango kernel powder dried at $50^{\circ}$ C. Jahurul et al. (2017) analyzed six varieties of mango in Malaysia and found fat in the range of $7.6-13.7 \%$ in MKP (freeze-dried) extracted by using supercritical carbon dioxide. Eleghede et al. (1995) and Ashoush and Gadallah (2011) reported protein content 6 and $7.76 \%$ respectively in MKP, which were similar to the result obtained. The analysis showed that treatment produces a significant reduction $(\mathrm{p}<0.05)$ in total ash content, while fat content was only increased $(p<0.05)$ by soaking. An increase in fat content in soaked kernel might be due to swelling of the kernel during soaking, as increase surface area induce efficient extraction of fat (Shashego, 2019).

Table 2

The functional properties of mango kernel flour

\begin{tabular}{llll}
\hline Sample & $\begin{array}{l}\text { Blanche } \\
\text { d mango } \\
\text { kernel } \\
\text { powder }\end{array}$ & $\begin{array}{l}\text { Soaked } \\
\text { mango } \\
\text { kernel } \\
\text { powder }\end{array}$ & $\begin{array}{l}\text { Untreated } \\
\text { mango } \\
\text { kernel } \\
\text { powder }\end{array}$ \\
\hline $\begin{array}{l}\text { Bulk density } \\
(\mathrm{g} / \mathrm{ml})\end{array}$ & $\begin{array}{l}0.51 \\
\pm 0.01 \mathrm{a}\end{array}$ & $\begin{array}{l} \pm .57 \\
\pm 0.01 \mathrm{~b}\end{array}$ & $\begin{array}{l}0.45 \\
\pm 0.02 \mathrm{c}\end{array}$ \\
\hline Oil Absorption & 72.60 & 60.00 & 80.00 \\
Capacity (\%) & $\pm 1.51 \mathrm{a}$ & $\pm 2.00 \mathrm{~b}$ & $\pm 2.00 \mathrm{c}$ \\
\hline Water Absorption & 131.67 & 142.7 & 173.33 \\
Capacity (\%) & $\pm 6.5 \mathrm{a}$ & $\pm 2.50 \mathrm{~b}$ & $\pm 5.77 \mathrm{c}$ \\
\hline Wettability (s/g) & 37.33 & 17.33 & 35.33 \\
& $\pm 3.00 \mathrm{a}$ & $\pm 1.20 \mathrm{~b}$ & $\pm 0.24 \mathrm{c}$ \\
\hline Gelation & 9.00 & 9.00 & 9.00 \\
$(\%)$ & $\pm 0.00 \mathrm{a}$ & $\pm 0.00 \mathrm{a}$ & $\pm 0.00 \mathrm{a}$ \\
\hline $\begin{array}{l}\text { Angle of repose } \\
\left({ }^{\circ}\right)\end{array}$ & 63.00 & 70.33 & 67.00 \\
& $\pm 1.00 \mathrm{a}$ & $\pm 0.58 \mathrm{~b}$ & $\pm 1.00 \mathrm{c}$ \\
\hline Solubility $(\%)$ & 14.66 & 15.67 & 16.00 \\
& $\pm 0.57 \mathrm{a}$ & $\pm 0.57 \mathrm{a}$ & $\pm 1.00 \mathrm{a}$ \\
\hline
\end{tabular}

All data are the mean \pm standard deviation of its triplicates. Different letters in the same row indicate significant differences $(\mathrm{p}<0.05)$.

There was a significant reduction $(\mathrm{p}<0.05)$ in iron, calcium, and phosphorous of MKP produced by the treatment. Blanching and soaking may result in leaching loss of soluble components as reviewed by Moktan and Ojha (2016). According to Yatnatti et al. (2014), the iron content and calcium content in MKP (soaked and then blanched) is $12 \mathrm{mg} / 100 \mathrm{~g}$ and $170 \mathrm{mg} / 100 \mathrm{~g}$ respectively, while Elegbede et al. (1995) reported phosphorous content $140 \mathrm{mg} / 100 \mathrm{~g}$ in MKP. The calcium content in this study was found to be similar to the past result while iron and phosphorus were were found to be less.

\section{Functional properties of mango kernel powder}

The functional properties of mango kernel powder obtained from different treatments are shown in table 2 . The values were significantly different at $\mathrm{p}<0.05$.

Oil absorption capacity (OAC), water absorption capacity (WAC), and wettability of MKP decreased significantly $(p<0.05)$ after treatment, while bulk density increased significantly $(\mathrm{p}<0.05)$. The wettability of soaked MKP decreased significantly $(p<0.05)$, while it significantly increased for heated MKP $(\mathrm{p}<0.05)$. Legesse \& Emire (2012) reported bulk density of mango kernel flour grown in Ethiopia was $0.61 \mathrm{~g} / \mathrm{mL}$ and the value obtained in this study was slightly lower which might be due to the varietal difference. Bulk density is useful to study the potentiality of flour in complementary food (low bulk density) because we can feed more products with high nutritional density (Mepba et al., 2007; Chandra et al., 2015). WAC of the powder is dependent mainly on the amount and nature of the hydrophilic constituents and to some extent on the $\mathrm{pH}$ and nature of the protein (Owuarnanam et al., 2013). The ability of the protein to bind water is indicative of its water absorption capacity. Treatment (soaking and blanching) the kernels before the flour preparation led to a significant reduction $(\mathrm{p}<0.05)$ of WAC and OAC. Moreover, it shows that the MKP sample with the lowest wettability dissolves the fastest in water (Ubbor and Akobondu, 2009).

Chandra (2013) revealed that the flour having higher starch content gelatinizes at low temperatures. There was no significant difference in the gelation capacity of flour with the treated and control MKPs. The angle of repose is important in the proper design of hoppers to maintain a continuous flow of the flour. The angle of repose of powder samples in this study was found to be higher than as reviewed by Geldart et al. (2006). The angle of repose up to $35^{\circ}$ indicates free flowability and $35^{\circ}$ to $45^{\circ}$ indicates some cohesiveness.

\section{Analysis of Bioactive Compounds of MKP}

The result of bioactive compounds of mango kernel flour is shown in table 3 . The values of ascorbic acid, polyphenol, tannin, and flavonoid of MKP produced by soaking and blanching were significantly less $(p<0.05)$ compared to control, but antioxidant activity was only significantly reduced $(\mathrm{p}<0.05)$ by heat treatment. The heat treatment produced a significant reduction $(\mathrm{p}<0.05)$ in ascorbic acid (18.24\%), polyphenol content (4.7\%), tannin (76.44\%), and flavonoid (7.38\%) compared to untreated flour while soaking result in a significant reduction $(p<0.05)$ in ascorbic acid (13.1\%), polyphenol (3.47\%), tannin (63.73\%), and flavonoid (21.76\%).

The value of ascorbic acid (112-137.33 mg/100 g) content obtained was more than reported by Sogi et al. (2013), who found ascorbic acid in the range of $61.22-74.48 \mathrm{mg} / 100 \mathrm{~g}$ in mango kernel. The drying methods also affect the ascorbic content of mango kernel (Sogi et al., 2013). Blanching and soaking significantly reduced the ascorbic acid content of MKP. 
The polyphenol content of the samples ranged from $1630 \pm 0.67$ to $1645 \pm 5.71 \mathrm{mg} \mathrm{GAE} / 100 \mathrm{~g}$, and the flavonoid content of MKP ranged from 683 to $816 \mathrm{mg} \mathrm{GAE} / 100 \mathrm{~g}$. Sogi et al. (2013) reported the polyphenol content of mango kernel powder in the range of 11.23-20.03 g/100 g, while Abdel-Razik et al. (2012) reported $2.19 \mathrm{~g} / 100 \mathrm{~g}$. In contrast, Abdalla et al. (2007) reported polyphenol 112 $\mathrm{mg} / 100 \mathrm{~g}$ in mango kernel. Abdel-Razik et al. (2012) found polyphenols and flavonoids 17.4 and $3.33 \mathrm{~g} / 100 \mathrm{~g}$ seed of mango kernel. Dorta et al. (2012) and Dorta et al. (2014) reported flavonoid $1.3 \mathrm{~g} / 100 \mathrm{~g}$ and $0.95 \mathrm{~g} / 100 \mathrm{~g}$ respectively in mango kernel. The values reported were quite different from the result obtained, which might be due to the difference in the extraction method employed, variety, and the procedure of estimation. Polyphenols and flavonoids were reduced significantly $(\mathrm{p}<0.05)$ by blanching and soaking. This might be due to leaching loss.

According to the result, tannin content in mango kernel powder ranged from $179 \mathrm{mg} \mathrm{TAE} / 100 \mathrm{~g}$ to $893 \mathrm{mg}$ TAE $/ 100 \mathrm{~g}$. Gumte et al. (2018) reported tannin content 210 $\mathrm{mg} / 100 \mathrm{~g}$ in soaked and blanched mango kernel powder. The value was similar to the result obtained. Tannin content was high in the case of untreated kernel flour. It showed that there is a reduction in tannin content due to heat treatment and soaking.

Table 3

Bioactive compounds in MKP.

\begin{tabular}{|c|c|c|c|}
\hline Sample & $\begin{array}{l}\text { Blanched } \\
\text { mango } \\
\text { kernel } \\
\text { powder }\end{array}$ & $\begin{array}{l}\text { Soaked } \\
\text { mango } \\
\text { kernel } \\
\text { powder }\end{array}$ & $\begin{array}{l}\text { Untreated } \\
\text { mango } \\
\text { kernel } \\
\text { powder }\end{array}$ \\
\hline $\begin{array}{l}\text { Ascorbic acid } \\
(\mathrm{mg} / 100 \mathrm{~g})\end{array}$ & $\begin{array}{l}112.00 \\
\pm 6.00^{\mathrm{a}}\end{array}$ & $\begin{array}{l}119.33 \\
\pm 4.16^{\mathrm{a}}\end{array}$ & $\begin{array}{l}137.33 \\
\pm 7.50^{\mathrm{b}}\end{array}$ \\
\hline $\begin{array}{l}\text { Polyphenol (mg } \\
\text { GAE/100 g) }\end{array}$ & $\begin{array}{l}1553.33 \\
\pm 30.00^{\mathrm{a}}\end{array}$ & $\begin{array}{l}1573.33 \\
\pm 15.00^{\mathrm{a}}\end{array}$ & $\begin{array}{l}1630.00 \\
\pm 10.00^{b}\end{array}$ \\
\hline $\begin{array}{l}\text { Tannin }(\mathrm{mg} \\
\text { TAE/100 g) } \\
\text { Flavonoid (mg } \\
\text { GAE/100 g) }\end{array}$ & $\begin{array}{l}235.00 \\
\pm 15.00^{\mathrm{a}} \\
773.33 \\
\pm 32.14^{\mathrm{a}}\end{array}$ & $\begin{array}{l}316.67 \\
\pm 20.80^{\mathrm{b}} \\
650.00 \\
\pm 20.00^{\mathrm{b}}\end{array}$ & $\begin{array}{l}873.33 \\
\pm 15.30^{c} \\
835.00 \\
\pm 25.00^{c}\end{array}$ \\
\hline $\begin{array}{l}\text { Antioxidant } \\
\text { activity }(\%) \\
(10000 \mathrm{ppm})\end{array}$ & $\begin{array}{l}68.33 \\
\pm 2.88^{\mathrm{a}}\end{array}$ & $\begin{array}{l}79.00 \\
\pm 6.55^{b}\end{array}$ & $\begin{array}{l}84.33 \\
\pm 4.04^{b}\end{array}$ \\
\hline
\end{tabular}

All data are the mean \pm standard deviation of its triplicates. Different letters in the same row indicate significant differences $(\mathrm{p}<0.05)$.

The tannin levels reported by Legesse and Emire (2012), after soaking at $30^{\circ} \mathrm{C}, 40^{\circ} \mathrm{C}$ and $50^{\circ} \mathrm{C}$ are $1.503 \mathrm{~g} / 100 \mathrm{~g}$, $1.350 \mathrm{~g} / 100 \mathrm{~g}$, and $1.203 \mathrm{~g} / 100 \mathrm{~g}$ respectively.

The obtained value of the antioxidant activity of mango seed extract $(1 \mathrm{~g} / 100 \mathrm{ml}=10000 \mathrm{ppm})$ ranges from $68-84 \%$, while Ribeiro et al. (2008) reported $67.7 \%$ by $5000 \mathrm{ppm}$ of extract. The higher antioxidant activity for the MSK extract may be due to the higher level of phenol present in the extract as the antioxidant activity has been found to be positively correlated with total phenol content as shown in Figure 1.

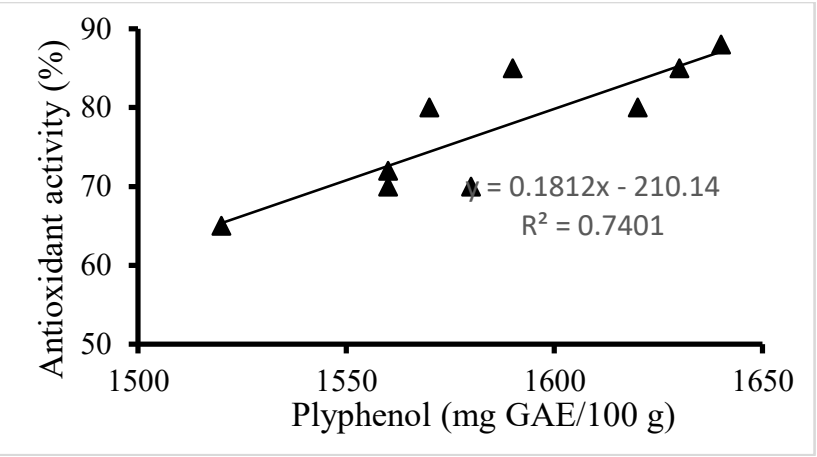

Figure 1. Correlation between polyphenol and antioxidant activity shown by mango kernel powder extract.

Antioxidant activity of a phenolic compound is due to free radical scavenging activity and metal chelation (Apak et al., 2007). A similar positive correlation was established by Puravankara et al. (2000).

\section{Conclusions}

The treatment (soaking and heating) not only produced a significant reduction in mineral content (iron, calcium, and phosphorous) of mango kernel powder (MKP) but also reduced phytochemicals (ascorbic acid, polyphenol, flavonoid, tannin). Decrease in water absorption capacity and oil absorption capacity after soaking and blanching prevails that untreated MKP has more potentiality for complimentary food preparation. Further research can be carried out to see its implication on complimentary food.

\section{Acknowledgments}

This research is carried out on the support of the Nepal Agricultural Research Council (NARC).

\section{References}

Abdalla, A. E., Darwish, S. M., Ayad, E. H., \& ElHamahmy, R. M. (2007). Egyptian mango by-product 1. Compositional quality of mango seed kernel. Food Chemistry, 103(4): 1134-1140.

Abdel-Razik, M. M., Ashoush, I. S., \& Yassin, N. M. N. (2012). Characteristics of mango seed kernel butter and its effects on quality attributes of muffins. Alexandria Journal of Food Science and Technology, 9(2): 1-9.

Altendorf, S (2017). Global prospects for major tropical fruits: Short-term outlook, challenges and opportunities in a vibrant global market place. Food and Agriculture Organization of the United Nations (FAO), pp 69-81.

AOAC. 2005. Official Methods of Analysis of AOAC International. 18th ed. Gaithersburg (MD): AOAC International.

Arogba, S. S. (1997). Physical, chemical and functional properties of Nigerian mango (Mangifera indica) kernel and its processed flour. Journal of the Science of Food and Agriculture, 73(3): 321-328.

Apak, R., Güçlü, K., Demirata, B., Özyürek, M., Çelik, S. E., Bektaşoğlu, B., Berker, K.I. \& Özyurt, D. (2007). Comparative evaluation of various total antioxidant 
capacity assays applied to phenolic compounds with the CUPRAC assay. Molecules, 12(7): 1496-1547.

Arogba, S. S. (1999). The performance of processed mango (Mangifera indica) kernel flour in a model food system. Bioresource Technology, 70(3): 277-281.

Ashoush, I. S., \& Gadallah, M. G. E. (2011). Utilization of mango peels and seed kernels powders as sources of phytochemicals in biscuit. World Journal of Dairy \& Food Sciences, 6(1): 35-42.

Bandyopadhyay, K., Chakraborty, C., \& Bhattacharyya, S. (2014). Fortification of mango peel and kernel powder in cookies formulation. Journal of Academia and Industrial Research, 2(12), 661-664.

Chandra, S., Singh, S., \& Kumari, D. (2015). Evaluation of functional properties of composite flours and sensorial attributes of composite flour biscuits. Journal of Food Science and Technology, 52(6), 3681-3688.

Cahndra, S. (2013). Assessment of functional properties of different flours. African Journal of Agricultural Research, 8(38): 4849-4852.

Dorta, E., Lobo, M. G., \& Gonzalez, M. (2012). Reutilization of mango byproducts: Study of the effect of extraction solvent and temperature on their antioxidant properties. Journal of Food Science, 77(1): C80-C88.

Dorta, E., Gonz_alez, M., Lobo, M. G., S_anchez-Moreno, C., \& de Âncos, B. (2014). Screening of phenolic compounds in by-product extracts from mangoes (Mangifera indica L.) by HPLC-ESI-QTOF-MS and multivariate analysis for use as a food ingredient. Food Research International, 57: 51-60.

Eleazu, C., Eleazu, K., Aniedu, C., Amajor, J., Ikpeama, A., \& Ebenzer, I. (2014). Effect of partial replacement of wheat flour with high quality cassava flour on the chemical composition, antioxidant activity, sensory quality, and microbial quality of bread. Preventive Nutrition and Food Science, 19(2): 115.

Elegbede, J. A., Achoba, I. I., \& Richard, H. (1995). Nutrient composition of mango characteristics of seed kernel from Nigeria. Journal of Food Biochemistry, 19(5): 391-398.

Elgailani, I. E. H., \& Ishak, C. Y. (2014). Determination of tannins of three common Acacia species of Sudan. Advances in Chemistry, Article ID 192708:1-5.

FAO (2019). Major tropical fruits market review. Food and Agriculture Organization of the United Nations.

Gadallah, M. G. E., \& Fattah, A. A. (2011). The antibacterial effect of mango seed kernel powder in minced beef during refrigerated storage. World Journal of Dairy \& Food Sciences, 6(2): 219-228.

Geldart, D., Abdullah, E. C., Hassanpour, A., Nwoke, L. C., \& Wouters, I. (2006). Characterization of powder flowability using measurement of angle of repose. China Particuology, 4(03n04): 104-107.

Gumte, S. V., Taur, A. T., Sawate, A. R., \& Kshirsagar, R. B. (2018). Effect of fortification of mango (Mangifera indica) kernel flour on nutritional, phytochemical and textural properties of biscuits. Journal of Pharmacognosy and Phytochemistry, 7(3): 16301637.

Jahurul, M. H. A., Zaidul, I. S. M., Ghafoor, K., AlJuhaimi, F. Y., Nyam, K. L., Norulaini, N. A. N., Sahina, F. \& Omar, A. M. (2015). Mango (Mangifera indica L.) by-products and their valuable components: A review. Food chemistry, 183: 173-180.

Jahurul, M. H. A., Zaidul, I. S. M., Norulaini, N. N. A., Sahena, F., Jaffri, J. M., \& Omar, A. M. (2014). Supercritical carbon dioxide extraction and studies of mango seed kernel for cocoa butter analogy fats. CyTA-Journal of Food, 12(1), 97-103.

Kanpairo, K., Usawakesmanee, W., Sirivongpaisal, P., \& Siripongvutikorn, S. (2012). The compositions and properties of spray dried tuna flavor powder produced from tuna precooking juice. International Food Research Journal, 19 (3): 893-899.

Legesse, M. B., \& Emire, S. A. (2012). Functional and physicochemical properties of mango seed kernels and wheat flour and their blends for biscuit production. African Journal of Food Science and Technology, 3(9): 193-203.

Mahdavi, R., Nikniaz, Z., Rafraf, M., \& Jouyban, A. (2011). Determination and comparison of the total polyphenol contents of fresh and commercial fruit juices. British Food Journal, 113(6): 744-752.

Menon, L., Majumdar, S. D., \& Ravi, U. (2014). Mango (Mangifera indica L.) kernel flour as a potential ingredient in the development of composite flour bread. Indian journal of Natural Products and Resources, 5(1): 75-82.

Mepba, H. D., Eboh, L., \& Nwaojigwa, S. U. (2007). Chemical composition, functional and baking properties of wheat-plantain composite flours. African Journal of Food, Agriculture, Nutrition and Development, 7(1): 1-22.

Moktan, K., \& Ojha, P. (2016). Quality evaluation of physical properties, antinutritional factors, and antioxidant activity of bread fortified with germinated horse gram (Dolichus uniflorus) flour. Food Science \& Nutrition, 4(5): 766-771.

Mutua, J. K., Imathiu, S., \& Owino, W. (2017). Evaluation of the proximate composition, antioxidant potential, and antimicrobial activity of mango seed kernel extracts. Food Science \& Nutrition, 5(2): 349-357.

Noorfarahzilah, M., Lee, J. S., Sharifudin, M. S., Fadzelly, M. A., \& Hasmadi, M. (2014). Applications of composite flour in development of food products. International Food Research Journal, 21(6): 2061-2074.

Nwosu, J. (2011). The Effect of Storage Condition on the Rheological/Functional Properties of Soup Thickner Mucuna sloanei (Ukpo). Researcher, 3(6): 27-32.

Nwosu, J. N., Owuamanam, C. I., Omeire, G. C., \& Eke, C. C. (2014). Quality parameters of bread produced from substitution of wheat flour with cassava flour using soybean as an improver. American Journal of Research Communication, 2(3): 99-118.

Okpala, L. C., \& Gibson-Umeh, G. I. (2013). Physicochemical properties of mango seed flour. Nigerian Food Journal, 31(1): 23-27.

Onuegbu, N. C., Nworah, K. O., Essien, P. E., Nwosu, J. N., \& Ojukwu, M. (2013). Proximate, Functional and Anti-nutritional Properties of Boiled Ukpo Seed (Mucuna flagellipes) Flour. Nigerian Food Journal, 31(1): 1-5. 
Owuarnanarn, C. I., Iwuoha, C. I., Onuegbu, N. C., Ogueke, C. C., \& Nwosu, J. N. (2013). Quality Characteristics of Processed Flours from Trifoliate Yarn (Dioscorea dumetorum) as Influenced by Steeping and Boiling in Varying Concentration of Trona Solution over Time. American Journal of Food Technology, 8(3):162-172.

Puravankara, D., Boghra, V., \& Sharma, R. S. (2000). Effect of antioxidant principles isolated from mango (Mangifera indica L) seed kernels on oxidative stability of buffalo ghee (butter-fat). Journal of the Science of Food and Agriculture, 80(4): 522-526.

Ranganna, S. (2002). Hand Book of Analysis of quality control for fruit and vegetable products 2 nd Ed. TATA Megraw Hill pub. Co. Ltd. New Delhi.

Ribeiro, S. M. R., Barbosa, L. C. A., Queiroz, J. H., Knödler, M., \& Schieber, A. (2008). Phenolic compounds and antioxidant capacity of Brazilian mango (Mangifera indica L.) varieties. Food Chemistry, 110(3): 620-626.

Schieber, A., Stintzing, F. C., \& Carle, R. (2001). Byproducts of plant food processing as a source of functional compounds - recent developments. Trends in Food Science \& Technology, 12(11): 401-413.

Shashego, Z. (2019). Effects of soaking time and temperature on the nutritional content and sensory quality of soybean flour and milk. Global Journal of Science Frontier Research: D Agriculture and Veterinary, 1(3): 25-38.

Shittu, T. A., \& Lawal, M. O. (2007). Factors affecting instant properties of powdered cocoa beverages. Food Chemistry, 100(1): 91-98.

Sigdel, A., Ojha, P., \& Karki, T. B. (2018). Phytochemicals and syneresis of osmo-dried mulberry incorporated yoghurt. Food Science \& Nutrition, 6(4): 1045-1052.

Sogi, D. S., Siddiq, M., Greiby, I., \& Dolan, K. D. (2013). Total phenolics, antioxidant activity, and functional properties of 'Tommy Atkins' mango peel and kernel as affected by drying methods. Food Chemistry, 141(3): 2649-2655.

Solís-Fuentes, J. A., \& Durán-de-Bazúa, M. C. (2004). Mango seed uses: thermal behaviour of mango seed almond fat and its mixtures with cocoa butter. Bioresource Technology, 92(1): 71-78.

Torres-León, C., Rojas, R., Contreras-Esquivel, J. C., Serna-Cock, L., Belmares-Cerda, R. E., \& Aguilar, C. N. (2016). Mango seed: Functional and nutritional properties. Trends in Food Science \& Technology, 55: 109-117.

Ubbor, S.C. and Akobondu, E.N.T. (2009). Quality characteristics of cookies from composite flours of watermelon seed, cassava and wheat. Pakistan Journal of Nutrition, 8(7): 1097-1102.

Walvekar, S., Kaimal, P. 2014. Comparitive study of effect of physical and chemical mutagens on phytochemical content and antioxidant activity of Aegle marmelos. International Journal of Advanced Research, 2(3): 590595.

Yatnatti, S., Vijayalakshmi, D., \& Chandru, R. (2014). Processing and nutritive value of mango seed kernel flour. Current Research in Nutrition and Food Science Journal, 2(3): 170-175. 